\title{
TRICHOSANTHESDIOICA ROXB: A PHARMACOGNOSY AND PHYTO - PHARMACOLOGICAL REVIEW
}

\author{
Senthamil Kavitha ${ }^{1^{\star}}$ and Kumudavalli ${ }^{2}$ \\ ${ }^{1}$ Department of Pharmacy, Thanjavur Medical College, \\ Thanjavur-613 004, Tamil Nadu, India. \\ ${ }^{2}$ Department of Pharmaceutical Chemistry, Vinayaka Missions \\ College of Pharmacy, Salem- 636 008, Tamil Nadu, India.
}

\begin{abstract}
Medicinal plants have a major role to protect human healthy life. The family cucurbitaceae contains nearly about 95 genera and 965 species. Generally they are the vine plants. Amongst all, the Trichosanthes DioicaRoxb has high traditional and medicinal value for maintaining the healthy life. Traditionally the plant is used as highly effective in skin disease, such as Bacterial skin infection, fungal infection, wound healing It is also effective agents in purgative, leprosy, jaundice, fever, diabetes, expectorant, aphrodisiac, appetizer, febrifuge, anthelmintic, stomachic , cancer-like conditions. It is a good antioxidant and blood purifier. This activity of the plant contains due to various phytochemical constituents present in Trichosanthesdioica are vitamin A, vitamin C, tannins, and Saponin. Seeds of Trichosanthesdioica also contain lectin, a carbohydrate (specifically galactose) \& large amount of peptides.Root contains amorphous saponin, hentriacontane, essential oil, fixed oil.The aim of this article is to explain the details of phyto-pharmacological properties of Trichosanthes DioicaRoxb for the future research work.
\end{abstract}

Keywords: Trichosanthesdioica Roxb, Pharmacognosy, Phytochemical constituent and review.

\section{INTRODUCTION}

Herbal medicines are plant derived materials and preparations with therapeutic (or) other human health benefits. Which container either raw (or) processed ingredient from one (or) more plants, inorganic materials or animal origin. Herbal medicine preparations are developed drugs created by the modern pharmaceutical industry. Now a day, they are manufactured and sold. than 80,000 are medicine. India is one of the world's 12 biodiversity centers with the presence of over 45,000 different plant species, one of them is TrichosanthesdioicaRoxb, Family: Cucurbitaceae and commonly known as Kambupudalai (Tamil), Parwal (Hindi), Thondekaye (Kannada), Potal (Telugu) Patolam (Malayalam), Potol (Sanskrit), Parora (Urdu), Potala (Odia). The plant is an important vegetable-grown extensively in Sambalpur, Orissa.

\section{MORPHOLOGY, $Y^{2,57}$}

The plant is a perennial, dioetious, and grows as a vine. Vines are pencil thick in size with dark green cordate, ovate, oblong, not lobed, rigid, leaves. Roots are tuberous with long tap root system. Flowers are tubular white with 1619 days initiation to anthesis for pistillate flowers and 10-14 days for staminate flowers. Stigma remains viable for approximately 14 hours and $40-70 \%$ of flowers set fruit based on shape, size, and striation, fruit can be grouped in to four categories long, dark green with white stripes, $10-13 \mathrm{~cm}$ long thick, dark green with very pale green stripes, $10-16 \mathrm{~cm}$ long roundish, dark green with white stripe, $5-8 \mathrm{~cm}$ long tapering, green and striped, $5-8 \mathrm{~cm}$ long.

\section{HABITAT $^{2,57}$}

Trichosanthes dioica, a genus of family cucurbitaceae, is an annual (or) perennial herb distributed in tropical Asia, Polynesia, and Astralia. It is cultivated throughout the plain of 
North India. (Fig.1: Plate No.443 Trichosanthesdioica Roxb).

Biological Source and Family

Trichosanthesdioica (Cucurbitaceae)

\section{Synonym}

Pointed Gourd, Parwal.

Scientific classification: ${ }^{2}$,

$\begin{array}{lll}\text { Kingdom } & : & \text { Plantae } \\ \text { Division } & : & \text { Magnoliophyta } \\ \text { Class } & \vdots & \text { Magnoliopsida } \\ \text { Order } & \vdots & \text { Cucurbitales } \\ \text { Family } & : & \text { Cucurbitaceae } \\ \text { Genus } & : & \text { Trichosanthes } \\ \text { Species } & : & \text { Dioica }\end{array}$

\section{MORPHOLOGY STUDIES}

The crude drugs used in the formulation Patoladikwathachurna are viewed macroscopically through the naked eyes and the results are tabulated as follows (Table 1: Results of Macroscopical Studies)

\section{POWER MICROSCOPY}

The individual crude drug powders used in the formulation are viewed microscopically and the following features are noted (Fig. 3: Characters from PatolaTrichosanthesdioica Roxb.- leaf).

Quantitative physico-chemical analysis of Trichosanthes dioicaroxb. Foreign organic matter

The foreign organic matter present in the raw materials was removed by mechanical method and the results were tabulated. It was found to be within the limits as per API. (Table 2: determination of foreign organic matter).

The various ash value such as total ash, acidinsoluble ash and water soluble ash are determined and the results were tabulated. It was found to be within the limits as per API. (Table 3: Ash value)

The various extractive values such as water soluble extractive, alcohol soluble extractive and results were tabulated. The results obtained are found to be within the limits as per API. (Table 4: determinations of extractive values)

\section{Phytochemical constituent ${ }^{1,14,}$}

The preliminary phytochemical study of TrichosanthesdioicaRoxb revealed the presence of a steroidal saponin, 24- $\alpha$-ethyl-20one-7-hydro-stigmast-8 $\beta, \quad 14 \beta$-di-3-O- $\beta$-Dxylofuranoside has been isolated from the leaves. Root contains-Amorphous saponin, hentriacontane, colocynthin, trichosanthin, essential oil, fixed oil. Seeds of Trichosanthesdioica also contain lectin, a carbohydrate (specifically galactose) \& large amount of peptides linoleic, oleic, oleostearic acids. Nicotinic acid, riboflavin, vitamin C, thiamin, 5-hydroxytryptamine has been isolated from the fruits. Cucurbita-5, 24-dienol also in mature plant (Table 5: Preliminary Phytochemical Screening of powdered raw material of Trichosanthesdioca Roxb. (leaf)).

\section{TLC studies of raw material \& patoladikwathachurna \\ Apiumleptophyllum \\ Mobile phase - Toluene : Ethyl acetate (9.3:0.7) \\ Stationary phase - Silica gel $60 \mathrm{~F}_{366} \mathrm{~nm}$ \\ Detecting agent - UV $366 \mathrm{~nm}$ \\ Solvent front $-10 \mathrm{~cm}$}

\section{PHYTO-PHARMACOLOGY \\ Antidiabetic activity ${ }^{9}$}

The aqueous extract of Trichosanthesdioica fruits by given dose of $1000 \mathrm{mg} / \mathrm{kg}$ body weight daily once for 28 days, it has reduced the levels of fasting blood glucose, postprandial glucose, asparate amino transferase, alkaline phosphatase, creatinine, urine sugar, and urine protein where as total protein and body weight was increased. No toxic effect was observed during LD50. Thus Trichosanthesdioica is a potent phytomedicine for diabetes

\section{Anxiolytic activity ${ }^{10}$}

The anxiolytic activity was evaluated by using Elevated plus and behavior models. The efficacy of the given aqueous extract Trichosanthesdioicawas 100 and $500 \mathrm{mg} / \mathrm{kg}$ compared to the standard anxiolytic drug Diazepam $2 \mathrm{mg} / \mathrm{kg}$. The result has shown the aqueous extract significantly increased the number of entries and time spent in the open arm and in the elevated plus maze. The aqueous extract showed the conformation of significant anxiolytic activity.

\footnotetext{
Haemolytic anaemia activity ${ }^{11}$

The aqueous extract of Trichosanthesdioica fruits were tested for their effects on the hemoglobin concentration $(\mathrm{Hb})$, red blood cell count (RBC), reticulocyte count, packed cell volume, cell shape, morphology and osmotic resistance in the phenyl hydrazine induced haemolytic anemia model in albino rats. The recovery study revealed that after 16 days, and the group of anaemic rats treated with the aqueous extract of Trichosanthesdioica fruits
} 
exhibited significantly ( $P \leq 0.01)$ improvement in haemoglobin concentration, red blood cell count, packed cell volume (mean values are being $14.15 \mathrm{gm} / \mathrm{dl}, 7.66$ 106/1, 0.75\%, 48.4\% respectively) when compared to group of anaemic rats left untreated (mean values are 8.54gm / dl, 4.16 106/1, 1.316\%, 39.16\%). Thusthe aqueous extract of Trichosanthesdioica fruits Significantly altered values and most of the parameters associated with haemolytic anemia.

\section{Antioxidant, anti-inflammatory and anti- pyretic activity $^{12}$}

The Methanolic extract along with organic soluble fraction of the fruits of TrichosanthesdioicaRoxb was designed to investigate the antioxidant, anti-inflammatory, \& antipyretic potential. Antioxidant activity was evaluated by DPPH (1,1-diphenyl-2picrylhydrazyl) and nitric oxide scavenging assay method. Anti-inflammatory activity was assessed by carrageenan induced paw edema in rats and anti-pyretic activity weresudied for (Brewer's yeast-induced pyrexia) at a dose level of 100,200 , and $400 \mathrm{mg} / \mathrm{kg}$ body weight for Methanolic extract. $\mathrm{MeOH}$ extract showed a dose dependent \& significant $(p \leq 0.005, p \leq$ 0.05 ) anti-inflammatory \& antipyretic effect. Dichloromethane fraction and ethyl acetate fractions were exhibited similar activity using a dose of $200 \mathrm{mg} / \mathrm{kg}$ body weight in these models. The pharmacological activities of the dichloromethane fraction were lesser than that of the Methanolic extract and other fraction. The methanolic extract or Trichosanthesdioica \& its ethyl acetate fraction given potent antioxidant, anti-inflammatory, \& antipyretic agent.

\section{Wound healing activity ${ }^{13}$}

The Methanolic extract of the Trichosanthes dioica Roxb fruit was evaluated for the wound healing potential. The incision of wounds were conflicted upon three groups of six rats each. Group I was treated with control (ointment base), Group II was treated with standared silver sulphadiazine $(0.01 \%)$ cream. Group III was treated with Methanolic extract ointment. Parametres were observed such as, percentage of wound concentration, epithelialization period, hydroxyproline content, tensile strength including histopathological studies. Results-the Methanolic extract Trichosanthes dioica Roxb fruit ointment showed significant $(P \leq 0.01)$ healing in both wound models when compare to control group.

\section{Laxative activity ${ }^{14}$}

To evaluate the laxative activity of the aqueous extract Trichosanthes dioica Roxb root in swiss albino mice by given dose 100 and 200 $\mathrm{mg} / \mathrm{kg}$ body weight. It was evaluated by excretory bowel activities in non-constipated \& in drug loperamide induced constipation in mice. The gastrointestinal transit was measured in both non-constipated and in constipated mice. Caster oil $(0.5 \mathrm{ml} /$ mouse per ox) used as reference. The aqueous extract of Trichosanthes dioica Roxb root at $200 \mathrm{mg} \mathrm{kg} \mathrm{(-1)} \mathrm{body} \mathrm{weight} \mathrm{was} \mathrm{found} \mathrm{and} \mathrm{the}$ results given most active, causing diarrhea in mice.

\section{Gastric antiulcer activity ${ }^{15}$}

The aqueous extract of Trichosanthes dioica Roxb leaves was evaluated as antiulcer activity against: (1) Aspirin plus pylorus ligation model, (2) Ethanol / Hcl-induced ulcer in wister rats. Using standard drug Ranitidine $(100 \mathrm{mg} /$ $\mathrm{kg}$ ), compard with Trichosanthes dioica leaves aqueous extract. Only the aqueous extract Trichosanthes dioica Roxb (500 mg / kg) significantly $(p \leq 0.001)$ increased the $\mathrm{pH}$ of gastric acid and reduced the volume of gastric juice, free and total acidities, reduced the ulcer index used in all models.

\section{Antimicrobial activity ${ }^{16}$}

In this study deals with the in vitro assessment of antimicrobial activity in different concentration and different parts of Trichosanthesdioica extract. Different bacterial strains were used in the disc diffusion method. Using parts of Trichosanthesdioica is leaves, fruits and seeds all three can be used as antibacterial agents. Only the leaves extract was active agent for all five strains and the highest zone of inhibition was observed against Mycobacterium smegmatis and also used for tuberculosis treatment.

\section{CONCLUSION}

Trichosanthes dioica Roxb is a widely traditionally used and more potent medicinal plant among all the thousands of medicinal plants. The pharmacological activity was reported in the present review confirmed that the therapeutic value of Trichosanthes dioica Roxb is much more. The presence of phytochemical constituents and pharmacological activities proved that the plant has a potential leading capacity for the development of new good therapeutic efficacy drugs in the future. 


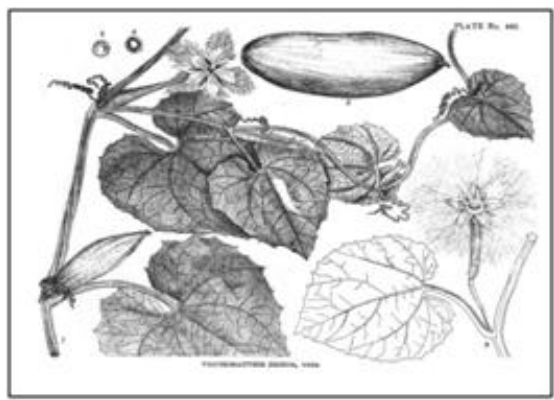

Fig.1: Plate No.443

Trichosanthesdioica Roxb



Fig. 2: Morphology and scaling of Trichosanthesdioica Roxb

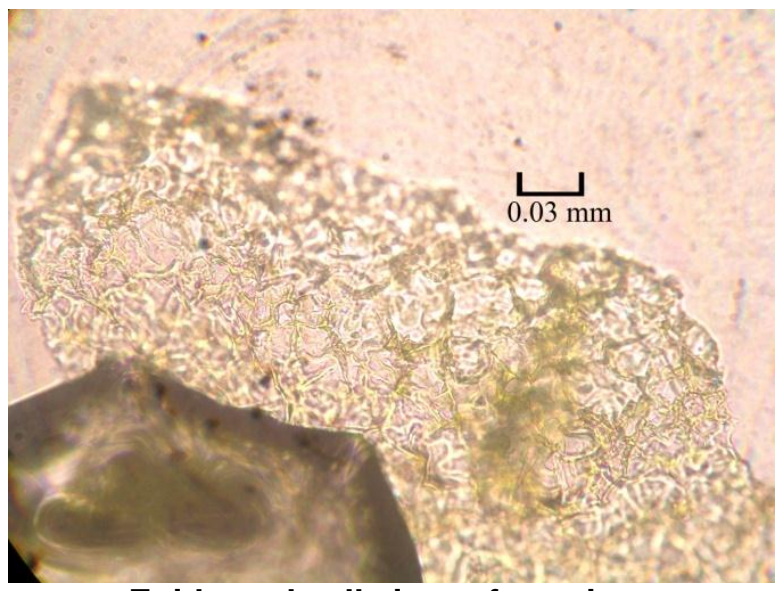

Epidermal cells in surface view

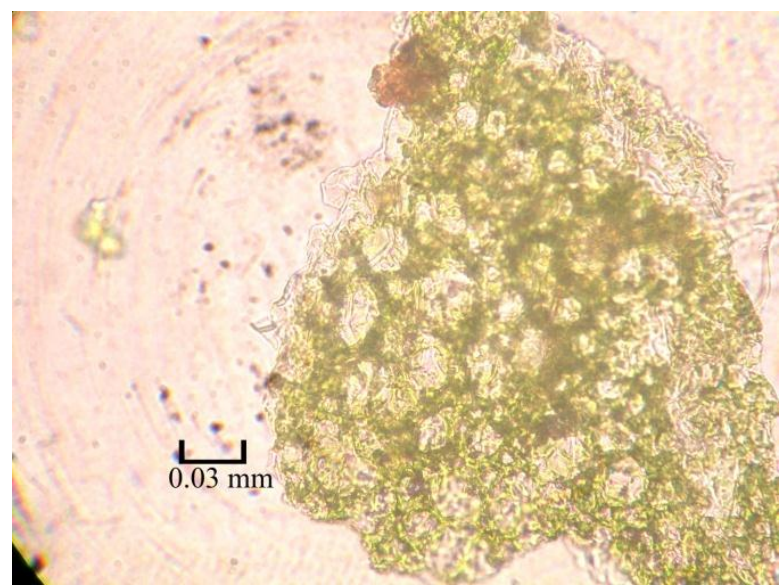

Spongy parenchyma under epidermis 


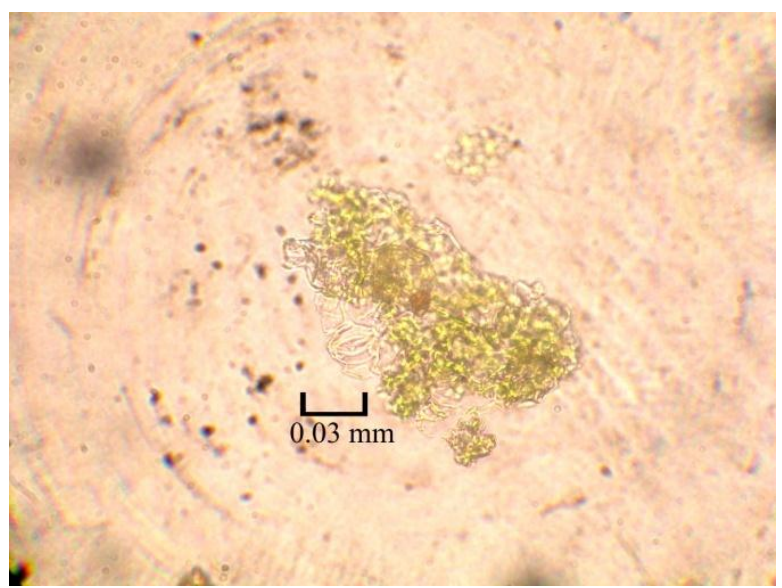

Stomata

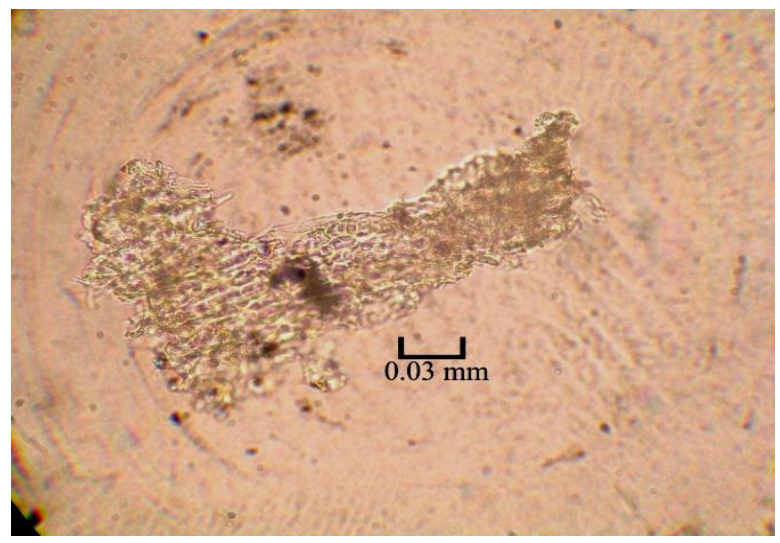

Fragment of phloem tissue

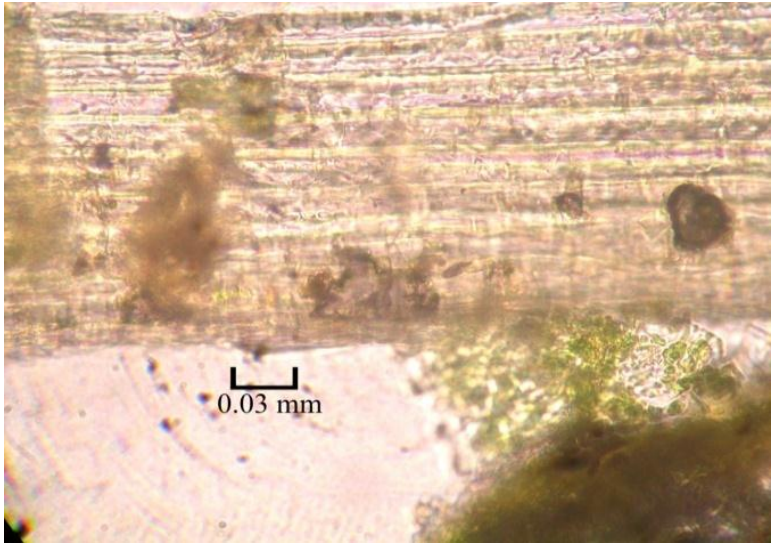

Fibre bundle

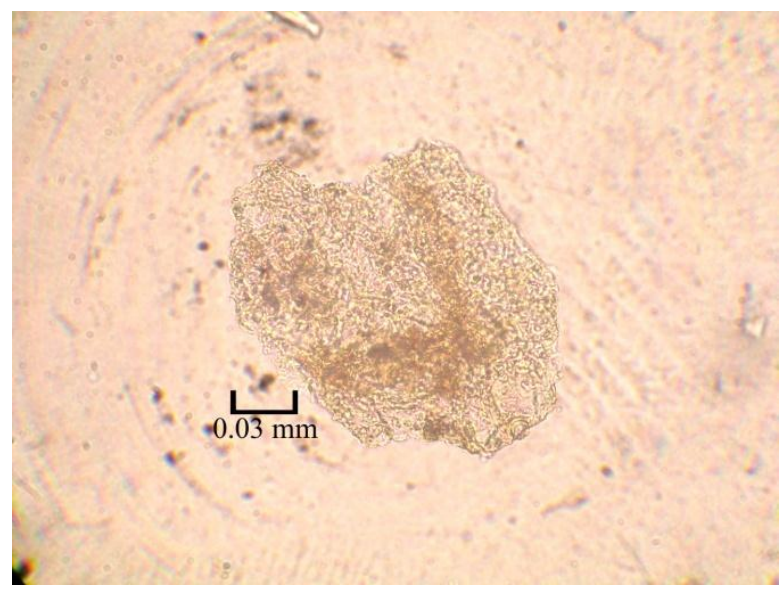

Epidermis of petiole with cicatrix

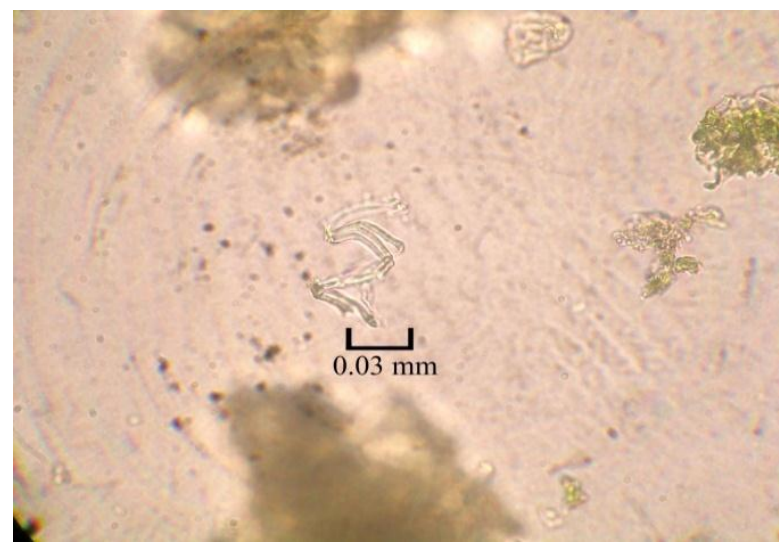

Vessel fragment

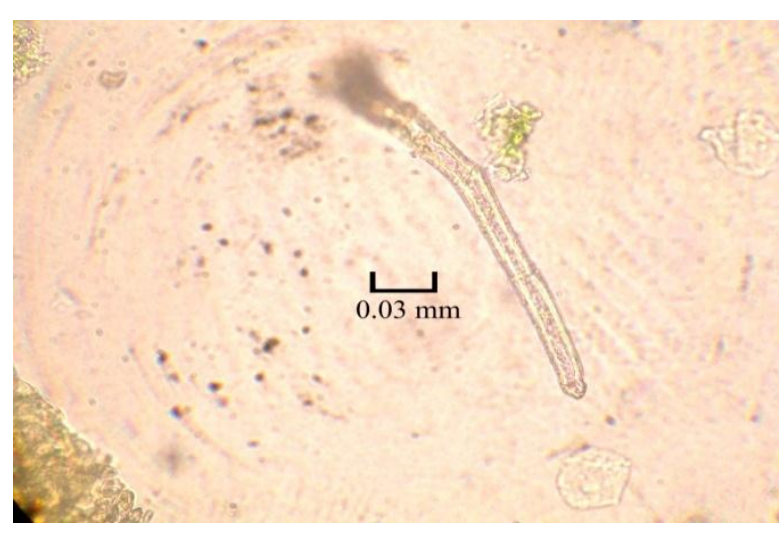

Trichome

Fig. 3: Characters from Patola- Trichosanthesdioica Roxb.- leaf 


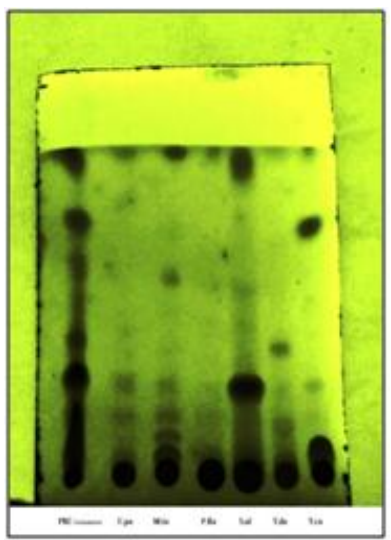

Fig. 4: TLC Identification of Six plants Extract Compared with PatoladiKwatha Churna Formulation

Patoladi Kvatha Churna
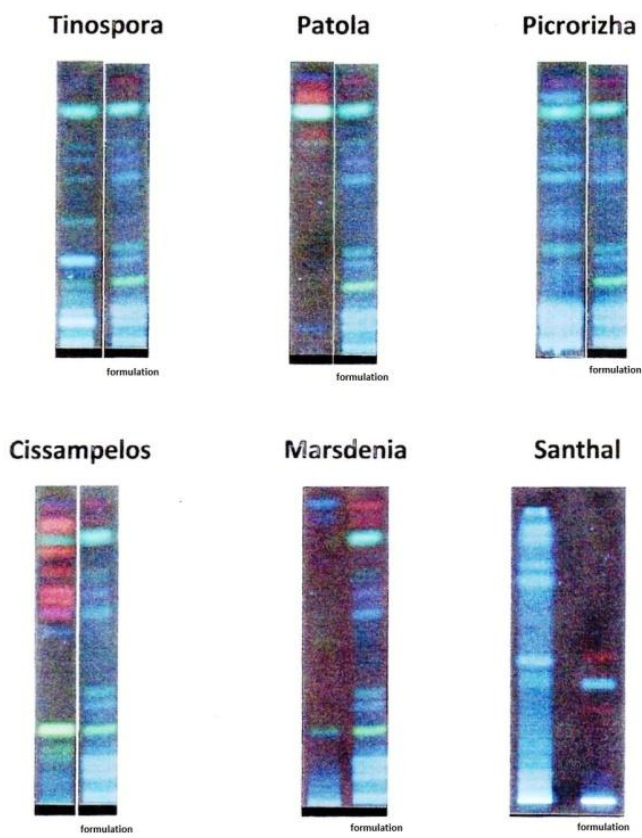

Fig. 5: HPTLC for patoladikvathachurna formulation (containing 6 plants) compared with individual plant extractespeciallytrichosanthesdioicaroxb(patola) 
Table 1: Results of Macroscopical Studies

\begin{tabular}{|c|c|c|c|c|c|c|}
\hline S.NO & Plant name & Colour & Odour & Taste & Surface characteristics & Size and shape \\
\hline 1 & Trichosanthesdioica Roxb & $\begin{array}{c}\text { Upper } \\
\text { surface } \\
\text { green, } \\
\text { lower } \\
\text { surface dull } \\
\text { green }\end{array}$ & Not specific & Slightly bitter & $\begin{array}{l}\text { Both surfaces are very } \\
\text { rough with rigid hairs. } \\
\text { Sinuate and dentate } \\
\text { margin, cordate base, } \\
\text { acute to acuminate apex. }\end{array}$ & $\begin{array}{l}\text { Ovate-oblong } \\
\text { Cordate }\end{array}$ \\
\hline
\end{tabular}

Table 2: Determination of foreign organic matter

\begin{tabular}{|c|c|c|c|c|c|}
\hline S.NO. & Plant name & Foreign organic matter & API Standard limit & Loss On Drying & PH \\
\hline $\mathbf{1}$ & TrichosanthesdioicaRoxb. & $1.0 \%$ & NIL & $7.8 \%$ & 8.19 \\
\hline
\end{tabular}

Table 3: Ash value

\begin{tabular}{|c|c|c|c|c|c|c|}
\hline S.No. & Plant name & $\begin{array}{c}\text { Determination } \\
\text { of ash value } \\
\text { (Total ash) }\end{array}$ & $\begin{array}{c}\text { API Standard } \\
\text { limit }\end{array}$ & $\begin{array}{c}\text { Acid } \\
\text { insoluble } \\
\text { ash }\end{array}$ & $\begin{array}{c}\text { API } \\
\text { Standard } \\
\text { limit }\end{array}$ & $\begin{array}{c}\text { Water } \\
\text { soluble } \\
\text { ash }\end{array}$ \\
\hline $\mathbf{1}$ & TrichosanthesdioicaRoxb. & $13.36 \%$ & $\mathrm{NMT}-7 \%$ & $3.14 \%$ & $\mathrm{NIL}$ & $\mathrm{NIL}$ \\
\hline
\end{tabular}

Table 4: Determinations of extractive values

\begin{tabular}{|c|c|c|c|c|c|}
\hline S.No. & Plant name & $\begin{array}{c}\text { Water soluble } \\
\text { extractive }\end{array}$ & $\begin{array}{c}\text { API } \\
\text { Standard } \\
\text { limit }\end{array}$ & $\begin{array}{c}\text { Alcohol soluble } \\
\text { extractive }\end{array}$ & API Standard limit \\
\hline $\mathbf{1}$ & TrichosanthesdioicaRoxb. & $12.5 \%$ & $\mathrm{NIL}$ & $2.1 \%$ & $\mathrm{NIL}$ \\
\hline
\end{tabular}

Table 5: Preliminary Phytochemical Screening of powdered raw material of Trichosanthesdioca roxb. (leaf)

\begin{tabular}{|c|c|c|}
\hline S.NO. & Chemical Constituent & $\begin{array}{c}\text { Trichosanthesdioca } \\
\text { Roxb. (leaf) }\end{array}$ \\
\hline 1 & Alkaloids & + \\
\hline 2 & Glycosides & - \\
\hline 3 & Carbohydrates & - \\
\hline 4 & Steroids & + \\
\hline 5 & Triterpenods & - \\
\hline 6 & Flavanoids & + \\
\hline 7 & Tannins & \\
\hline 8 & Phenoles & ++ \\
\hline 9 & Saponins & - \\
\hline 10 & Fixed oils and fats & - \\
\hline 11 & $\begin{array}{c}\text { Proteins \&Free amino } \\
\text { acids }\end{array}$ & - \\
\hline 12 & Volatile oil & - \\
\hline 13 & $\begin{array}{l}\text { Mucilage, gums and } \\
\text { resins }\end{array}$ & - \\
\hline 14 & Terpenoids & + \\
\hline 15 & Diterpenes & - \\
\hline
\end{tabular}

$(+)$ indicates Present and (-) indicates Absent

Table 6: Identification of PatoladiKvatha Churna with Trichosanthesdioica Roxb.

\begin{tabular}{|c|c|c|c|c|c|c|}
\hline \multirow{2}{*}{ No. } & \multirow{2}{*}{ Name of the plant extract } & \multirow{2}{*}{$\begin{array}{l}\text { No. } \\
\text { of } \\
\text { Spot }\end{array}$} & \multirow{2}{*}{$\mathbf{R}_{\mathrm{f}}$ Value } & \multicolumn{2}{|c|}{ PKC Formulation } & \multirow{3}{*}{$\begin{array}{c}\begin{array}{c}\text { Name of the matching } \\
\text { compound }\end{array} \\
\text { Steroids }\end{array}$} \\
\hline & & & & $\begin{array}{c}\text { No. of } \\
\text { Spot }\end{array}$ & $\mathbf{R}_{\mathrm{f}}$ Value & \\
\hline 1 & TrichosanthesdioicaRoxb & 4 & $0.15,0.3,0.4,0.5$ & 1 & 0.3 & \\
\hline 2 & TrichosanthesdioicaRoxb.(Patola) & 3 & $0.86,0.08,0.94$ & 3 & $\begin{array}{c}0.86,0.08 \\
0.94\end{array}$ & $\begin{array}{c}\text { 0.86- orange colour- } \\
\text { Flavonoids\&Steroids } \\
\text { 0.86-Brown colour- } \\
\text { Tanins\&Phenols,Aminoacids }\end{array}$ \\
\hline
\end{tabular}




\section{REFERENCES}

1. Senthamil Kavitha $M$, Radha $R$, Vadivu $R$ and Nartunai G. Phytochemical Screening and Antimicrobial Activity of Polyherbal Ayurvedic Formulation Patoladi Kvatha Churna for skin diseases: World Journal of Pharmacy and Pharmaceutical Sciences. 2018;7:1184-1202.

2. Senthamil kavitha $M$, Radha $R$, Vadivu R and Nartunai G. Raw Material Standardisation of $A$ Polyherbal Ayurvedic Formulation Patoladi Kvatha Churna for skin diseases: World Journal of Pharmacy and Pharmaceutical Sciences. 2018;1021-1030.

3. Raj, Prashantkumar, Jaiswal, Dolly, Raj, Devendra K, Sharma, Bechan, Watal and Geeta. Effect of water extract of Trichosanthesdioica fruits in streptozocin induced diabetic rats. Indian journal of clinical biochemistry. 2008;23(4):387-90.

4. Bhadoriya SS, Dixit PV, Bhoopendra, Raghuvashi, Ankit, Mangal, Narendra and Mandoria. Anxiolytic activity of aqueous extract of fruits of Trichosanthesdioica Roxb. Journal of Pharmacy Research. 2012;5(2):10571058.

5. Dhakar, Ranjana, Kumar KY, Kumar $\mathrm{PU}$ and Kumar PR. In vivo assessment of bioactivity of Trichosanthesdioica Roxb for the management of haemolytic anaemia. International Journal of Pharm Tech Research. 2012;4(2):689-699.

6. Alam MB, Hossain MS, Chowdhury NS, Asadujjaman M, Ronok Zahan, Islam MM, Mazumder MEH, Haque, ME and Anwarul Islam. Antioxidant, anti-inflammatory and anti-pyretic activities of Trichosanthesdioica Roxb fruits. Journal of Pharmacology and Toxicology. 2011;6(5):440-453.

7. Shivhare, Yogesh, Singour, Pradeep $\mathrm{K}$, Patil UK and Pawar RS. Wound healing potential of methanolic extract of Trichosanthesdioica Roxb fruits in rats. Journal of Ethnopharmacology. 2010; 127(3): 614-619.

8. Hattacharya, Sanjib and Haldar and Pallab Kanti. Trichosanthesdioica Roxb root possesses stimulant laxative activity in mice. Journal of Natural Product Research. 2012;26(10):952-957.
9. Hamdulay N, Attaurrahaman Z, Shende V and Lawar M. Evaluation of gastric antiulcer activity of Trichosanthesdioica Roxb. Leaves. International Journal of Pharmaceutical Sciences and Research. 2012;3(11):4332-4337.

10. Raj PK, Shikha Gupta RK and Geeta Watal. A novel antimicrobial agents Trichosanthesdioica. International Journal of Pharma and Bio Science. 2010;1(3):PS14-PS14.

11. Rajinder, Kaur, Ram RN and histological studies in common carp (Cyprinuscarpio) fed with pointeredgoured (Trichosanthedioica), Indian Journal of Veterinary Pathology. 2016;40:341-346.

12. Islam MA, Rashedul, Hasan and Rhyad-UI-Ferdous M. Evaluation of cytotoxic effect of Trichosanthesdioica (leaves) compared to vincristin sulphate in Bangladesh. World Journal of Pharmaceutical Research. 2016;5:196-207.

13. Nayak DA, Pradhan M, Mohanty S, Parida AK and Mahapatra P. Effect of integrated nutrient management on productivity and profitability of pointerd gourd (TrichosanthesdioicaRoxb). Journal of Crop and Weed. 2016;12:25-31.

14. Solomon JA, Aditya, Ganeshpurkar, Nilesh, Shrivastava, Divya, Bansal and Nazneen Dubey. Determination of cucurbitacin B in TrichosanthesdioicaRoxb by HPTLC; Journal: Pharmacognosy communications. 2014;4:8-12.

15. Sangeetha $G$, Srinivas $P$, Singh $H S$, Debasish $B$ and Bharathi LK. Fruit and Vine Rot of Pointered Gourd (TrichosanthesdioicaRoxb.) as influenced by planting systems and Weather parameters in East Cost Reion of India; Journal of pure and Applied Microbiology. 2016;10:28952900.

16. Kumar, Sanjeev, Singh, Hemant, Pandey, Vikramaditya and Singh BD. In vitro multiplication of pointeredgoured

(Trichosanthesdioica) through nodal explants culture, and testing the genetic fidelity of microprobagated plants using RAPD markers; Indian Journal of Biotecnology. 2016;4: 581588. 
17. Solomon JA, Aditya Ganeshpurkar, Nilesh, Shrivastava, Divya, Bansal and Nazneen Dubey. Protective effect of Trichosanthesdioica extract against gentamicin induced nephrotoxicity in rats. Journal Pharmacognosy communications. 2016;6:23-27.

18. Kabir, Syed Rashel, Rahman, MdMusfikur, Tasnim, Shahnima, Karim, Md Rezaul and Khatun, Nazma. Purification and characterization of a novelchitinase from Trichosanthesdioica seed with antifungal activity. International Journal of Biological Macromolecules. 2016;84:62-68.

19. Singh, Hemant, Kumar, Sanjeev and Singh BD. In vitro conservation of pointed gourd (Trichosanthesdioica) germplasm through slow-growth shoot cultures. Effect of flurprimidol and triiodobenzoic acid. Journal Scientia Horticulturae. 2015;182:4146.

20. Kishore, Kundan, Patnaik, Samiksha, and Shukla AK. Optimization of method to alleviate in vitro shoot tip necrosis in TrichosanthesdioicaRoxb. Indian Journal of Biotecnology. 2015; 14:107-111.

21. Manish, Kumar, Yadav RK and Deepmala Verma. Antidiabetic effect of Trichosanthesdioica and cocciniaindica in alloxan induced diabetic rats. Journal of Current Research in Science. 2014;2:567569.

22. Chaudhary SJ and Paranjape AN. Phytoconstituents

TrichosanthesdioicaRoxb. A herbal theraphy for nephrotoxicity. World Journal of Pharmacy and Pharmaceutical Sciences (WJPPS). 2014;3:1521-1552

23. Bhattacharya, Sanjib, Das, Sanjitkumar and Haldar Pallabkanti. Arsenic Induced Myocardial Toxicity in Rats. Alleviative Effect of Trichosanthesdioica Fruit. Journal of Dietary Supplements. 2014;11:248261.

24. Adikari, Sinchan, Saha, Souman, Bandyopadhyay, Tapas kumar and Ghosh Parthadeb. Identification and Validation of a new male sex-specific ISSR marker in pointed gourd (TrichosanthesdioicaRoxb.). The Scientific World Journal. 2014;216896-216896.
25. Srijita Dutta. Pharmacological Potentials TrichosanthesdioicaRoxb.

(Cucurbitaceae). An overview: International Journal of Drug Formulation and Research. 2015;6:110.

26. Sanjib, Bhattacharya and Haldar PK. Acute and sub-chronic toxicity study of Trichosanchesdioica root in mice. American-Euracian Journal of Toxicological Sciences (AEJTS). 2013;5:30-35.

27. Bhattacharya, Sanjib and Haldar, Pallabkanti. The triterpenoid fraction from Trichosanchesdioica root suppresses experimentally induced inflammatory ascites in rats. Journal Pharmaceutical Biotecnology. 2013;51:1477-1479.

28. Bhattacharya, Sanjib and Haldar, Pallabkanti: Neuropharmacological properties of Trichosanthesdioica root. Chinese journal of Natural Medicines. 2013;11:158-163.

29. Bhattacharya, Sanjib and Haldar, Pallabkanti. Trichosanthesdioica Root Alleviates Arsenic Induced Myocardial Toxicity in Rats. Journal of Environmental Pathology Toxicology and Oncology. 2013;32:251-261.

30. Bhattacharya, Sanjib and Haldar, Pallabkanti. Trichosanchesdioica Fruit Extract Ameliorates ArsenicInduced Brain Toxicity in Male Albino Rates. Journal of Environmental Pathology Toxicology and Oncology. 2013;32:141-148.

31. Sanjib, Bhattacharya and Haldar PK. Evaluation of antimitotic and genotoxic effects of the triterpenoid extract from Trichosanthesdioica root: American-Euracian Journal of Toxicological Sciences (AEJTS). 2012;4:20-23.

32. Sanjib, Bhattacharya and Haldar PK. Exploration of anti-nociceptive and locomotor effects of Trichosanthesdioica root extracts in Swiss albino mice. Asian Pacipic Journal of Biomedicine. 2012;S224228.

33. Rai $P$, Gupta $S$, Jayasundar $R$ and Watal G. A Scientific Validation of Antihyperglycemic and Antihyperlipedemic Attributes of Trichosanthesdioica fruits. Journal Annals of Nutrition Metabolism. 2013;63:1147-1147. 
34. Rai, Prashant kumar and Gupta. A Scientific Validation of Antihyperglycemic and Antihyperlipidemic Attributes of Trichosanthesdioica. 2013;473059.

35. Barma, Pranab and Jha and Shantanu. Insect and Non-Insect Pests Infesting Pointed Gourd (TrichosanthesdioicaRoxb.) in West Bengal. Journal Bioscan. 2013;8:537543.

36. Bhattacharya, Sanjib and Haldar, Pallabkanti. Chemopreventive property of Trichosanthesdioica Root Against 3-Methylcholanthreneinduced Carcinogenesis in Albino Mice. Journal of Environmental Pathology Toxicology and Oncology. 2012;31:109-119.

37. Bhattacharya, Sanjib and Haldar Pallabkanti. Ameliorative effect Trichosanthesdioica root against experimentally induced arsenic toxicity in male albino rats. Journal Environmental Toxicology and Pharmacology. 2012;33:394-402

38. Bhattacharya, Sanjib and Haldar Pallabkanti. Trichosanthesdioica Fruit Ameliorates experimentally Induced Arsenic Toxicity in Male Albino Rats Through the Alleviation of Oxidative Stress. Journal Biological Trace Element Research. 2012;48:232-241.

39. Bhattacharya, Sanjib and Haldar Pallabkanti. Protective role of the triterpenoid-enriched extract of Trichosanchesdioica root against experimentally induced pain and inflammation in rodents. Journal Natural Product Research. 2012;26:2348-2352.

40. Alom MS, Nag BL and Islam. Performance of different crop species with pointed gourd (TrichosanthesdioicaRoxb.).

Bangladesh Journal of Agricultural Research. 2013;38:523-529.

41. Amdadul, Huq, Shahina and Akter. In vitro microprobagation of pointed gourd (TrichosanthesdioicaRoxb.) from shoot tip and nodal segment. Bangladesh Journal of Scientific and Industrial Research. 2012;47:217222.

42. Shivhare, Yogesh, Singh and Priya. Antioxidant Potential of Trichosanchesdioica Roxb. (fruits) Pharmacognosy Journal. 2010;2:107111.

43. Komal and Rashmi. In Vitro Regeneration of Plantlets through
Callus Cultures in

Trichosanthesdioica Roxb. Journal: In Vitro Cellular and Development Biology-Animal. 2011;47:S40-S40.

44. Komal and Rashmi. In Vitro Plant Regeneration of Trichosanthesdioica Roxb. C.V.Hilli from Nodal Explants. Indian Journal of Agricultural Research. 2011;45:140-145.

45. Komal and Rashmi. One step method of plantlet regeneration in Trichosanthesdioica Roxb. An approach towards cost effective and shorter protocol. African Journal of Biotechnology. 2011;10:9-12.

46. Raj SK, Snehi SK and Khan. Molecular identification of an Ageratum enation virus isolate associated with mosaic disease of pointed gourd (Trichosanthesdioica) in India. 2011;39:497-502.

47. Shah BN and Seth AK. Pharmacological potential of Trichosanthesdioica - an edible plant. Hygeia - Journal for Drugs and Medicine. 2011;2:1-7.

48. Bairy KL, Adarsha KR and Annavi. Effect of Concomitant Administration of Aqueous Extract of Leaves of Trichosanthesdioica and Metformin in Diabetic Rats. Journal of Clinical Pharmacology. 2010;50:1077-1077.

49. Jamal, Farrukh, Qidwai and Tabish. Biocatalytic activity of immobilised pointed gourd (Trichosanthesdioica) peroxidise-concanavalin $A$ complex on calcium alginate pectin gel: Journal of Molecular Catalysis BEnzymatic. 2012;74:125-131.

50. Adiga, Shalini, Bairy and Et KL. Hypoglycemic effect of aqueous extract of Trichosanthesdioica in normal and diabetic rats: International Journal of Diabetes in Developing Countries. 2010;30:38-42.

51. Adikari $S$ and Biswas A. A Preliminary Report on the Genetic Variation in Pointed Gourd (Trichosanthesdioica Roxb.) As Assessed by Random Amplified Polymorphic DNA. Journal Acta Biologica Hungarica. 2014;65:156164.

52. Rai $P$, Kumar Rai, Kumar $D$ and Mehta. Effect of Trichosanthesdioica on Oxidative Stress and CYP450 Gene Expression Level in Experimentally Induced Diabetic Rats. 2011;57:31-39.

53. Kumar, Sanjeev and Singh BD. RAPD markers for identification of 
sex in pointed goured (TrichosanthesdioicaRoxb.). Indian Journal of Biotechnology. 2012;11:251-256.

54. Tiwari AK, Rao GP and Khan MS. Detection and elimination of Begomovirus infecting Trichosanthesdioica (pointed gourd) plants in Uttar Pradesh, India. Journal archives of Phytopathology and Plant Production. 2012;45:1070-1075.

55. Nanda, Satyabrata, Kar and Basudeba. Development of an ISSR based STS marker for sex identificatication in pointed gourd (TrichosanthesdioicaRoxb.). Journal Scientia Horticulture. 2013;150:1115.

56. Jamal, Farrukh, Singh and Sangram. Optimization of internal conditions for biocatalytic dye colour removal and a comparison of redox mediator's efficiency on partially purified Trichosanthesdioica peroxidise. Journal of Molecular Catalysis BEnzymatic. 2012;74:116-124.

57. Kumar, Nitin, Singh and Satyendra. Trichosanthesdioica Roxb. An overview Journal. Pharmacognosy reviews. 2012;6:61-7.
58. Farrukh and Jamal. Simple approach to reactive dye decolorization using Trichosanthesdioica proteins at low concentration of Ihydroxybenzotriazole. Journal current Trends in Biotechnology and Pharmacy. 2011;5:1273-1281.

59. Malek MA, Khanam D and Khatun M. In vitro culture of pointed gourd (TrichosanthesdioicaRoxb.).

Bangladesh Journal of Agricultural Research. 2010;35:135-142.

60. Malek MA, Mannan MA and Khanam D. In vitro regeneration through callus in pointed gourd (TrichosanthesdioicaRoxb.).

Bangladesh Journal of Agricultural Research. 2010;35:465-473.

61. Sanjeev, Kumar and Singh BD: Inheritance of stem and leaf morphological traits in pointed gourd (TrichosanthesdioicaRoxb.). Journal of Crop Improvement. 2008;22:225232.

62. Tiwari AK, Deepmala Singh and Tripathi. Effect of BAP and kinetin on shoot initiation of Trichosanthesdioica Roxb. An important medicinal plant. Journal Medicinal Plants. 2010;2:5961. 